\title{
Nitrogen fertilizer use efficiency in steer gain on old world bluestem
}

\author{
WILLIAM A. BERG AND PHILLIP L. SIMS
}

Authors are soil scientist and range scientist, respectively, at the USDA-ARS Southern Plains Range Research Station, 20001 Sth Street, Woodward, Okla. 73801.

\begin{abstract}
Old World bluestem (Bothriochloa ischaemum L.) is the major grass being planted for improved pastures on marginal farmland in western Oblahoma and adjacent areas in Texas. The farmland is often deficient in plant available $\mathrm{N}$ as a result of up to 100 years of cultivation and erosion. This study determined N fertilizer use efficiency on steer gain when grazing Old World bluestem in northwestern Oklahoma where average annual precipitation is $575 \mathrm{~mm} \mathrm{yr}^{-1}$. The study was conducted over 4 summer grazing seasons on Pratt soils (sandy, mixed thermic Psammentic Haplusalfs). Nitrogen rates of $0,34,68$, and $102 \mathrm{~kg} \mathrm{~N} \mathrm{ha}^{-1} \mathrm{yr}^{-1}$ were applied to paddocks in a randomized complete block design with 4 llocks. Steer gain averaged $220 \mathrm{~kg} \mathrm{ha}^{-1} \mathrm{yr}^{-1}$ and $3.3 \mathrm{~kg}$ per $\mathrm{kg} \mathrm{N}$ applied at the $34 \mathrm{~kg} \mathrm{~N} \mathrm{ha}^{-1} \mathrm{yr}^{-1}$ rate. Steer gain ranged from 2.3 to $4.3 \mathrm{~kg} \mathrm{vr}^{-1}$ per kg of $\mathrm{N}$ applied at the rate of $34 \mathrm{~kg} \mathrm{~N} \mathrm{ha}^{-1}$ $\mathrm{yr}^{1}$. Absut an additional $\mathrm{kg}$ of steer gain per $\mathrm{kg} \mathrm{N}$ applied was realized for the second $34 \mathrm{~kg} \mathrm{~N}^{-1} \mathrm{yr}^{-1}$ increment from 34 to 68 $\mathrm{kg} \mathrm{N} \mathrm{ha}{ }^{-1} \mathrm{yr}^{-1}$. Gain was negligible from the third $34 \mathrm{~kg} \mathrm{~N} \mathrm{ha}^{-1} \mathrm{yr}^{-1}$ increment from 68 to $102 \mathrm{~kg} \mathrm{~N} \mathrm{ha}^{-1} \mathrm{yr}^{-1}$. Early summer grazing of $\mathrm{N}$-fertilized Old World bluestem has high stocker production potential.
\end{abstract}

Key Words: Southern Plains, marginal farmland, grass fertilization, Borhriochloa ischaemum

Old World bluestem (Bothriochloa ischaemum L.) is the major grass being established for improved pastures on marginal farmland in western Oklahoma and adjacent areas in Texas. This warm-season grass is relatively easy to establish and has high forage production potential (Dewald et al. 1985). Steer gain on 70 $\mathrm{kg} \mathrm{N} \mathrm{ha}{ }^{-1}$ fertilized Old World bluestem averaged $200 \mathrm{~kg} \mathrm{ha}^{-1} \mathrm{yr}^{-1}$ under December through September grazing in western Oklahoma (Sims et al. 1983); steer gain on native rangeland in the area is about $50 \mathrm{~kg} \mathrm{ha}^{-1} \mathrm{yr}^{-1}$ (Shoop and Mcllvain 1971). Thus,

The aumors thank Ror Chamasson, Rick Hurst, John Loch, Lonnie Parsons, and Dan Persons for assistance in field work, Jery McLuughlin for laboratory analy'ses, Tom Popham for statistical analyses, and Sherry Dewald for manuscript preparation.

Manuscript accepted 27 Nov. 1994. the estimated 2 million ha of Old World bluestem established in Oklahoma and Texas has a high beef production potential. Some of this potential might be used to reduce summer grazing pressure on native rangeland.

Marginal farmland on the Southern Plains is deficient in $\mathrm{N}$ available to grass as a result of up to 100 years of cultivation and erosion. Clipping studies show a nearly linear Old World bluestem yield response to fertilizer $\mathrm{N}$ up to $70 \mathrm{~kg} \mathrm{~N} \mathrm{ha}^{-1} \mathrm{yr}^{-1}$ on these soils (Berg 1990). Clipping data would apply when stands are hayed, however, clipping data may not adequately predict grazing response with $\mathrm{N}$ fertilization since $\mathrm{N}$ is being recycled in urine and feces (Russelle 1992).

Nitrogen fertilization of Caucasian bluestem (B. caucasica (Trin.) C. E. Hubb.) at $40 \mathrm{~kg} \mathrm{~N} \mathrm{ha}^{-1} \mathrm{yr}^{-1}$ in western Oklahoma increased beef production from 115 to $200 \mathrm{~kg} \mathrm{ha}^{-1} \mathrm{yr}^{-1}$ for an average efficiency of $2.1 \mathrm{~kg}$ of beef produced per $\mathrm{kg}$ of $\mathrm{N}$ applied (1963, 1964, and 1965 annual reports, Southern Plains Range Research Station, Woodward, Okla., unpublished). This N fertilizer use efficiency in steer gain is similar to that summarized for warm-season grasses fertilized at $110 \mathrm{~kg} \mathrm{~N} \mathrm{ha}^{-1} \mathrm{yr}^{-1}$ in the southeastern USA (Wilkinson and Langdale 1974), and for introduced cool-season grasses fertilized at 45 to $50 \mathrm{~kg} \mathrm{~N} \mathrm{ha}^{-1} \mathrm{yr}^{-1}$ in western North Dakota (Rogler and Lorenz 1969, 1974). As N application rates increased $\mathrm{N}$ fertilizer use efficiency in beef gain decreased in southeastern USA (Wilkinson and Langdale 1974), North Dakota (Rogler and Lorenz 1969), and Australian studies (Jones 1990).

Beef gain response to pasture $\mathrm{N}$ fertilization may result from increases in forage production and/or greater average daily gain from higher quality forage. In western Oklahoma, average steer gain over 3 summers was $0.8 \mathrm{~kg} \mathrm{day}^{-1}$ on unfertilized and $1.0 \mathrm{~kg}$ day $^{-1}$ on N-fertilized Caucasian bluestem $(1963,1964$, and 1965 annual reports, Southern Plains Range Research Station, Woodward, Okla. unpublished). In North Dakota, early-season steer gain over 10 years averaged $1.2 \mathrm{~kg} \mathrm{day}^{-1}$ on unfertilized or $\mathrm{N}$-fertilized crested wheatgrass (Agropyron desertorum (Fisch. ex Link) Schult.) (Rogler and Lorenz 1969).

The objective of this study was to develop guidelines for $\mathrm{N}$ application rates and grazing management of Old World bluestem established on marginal farmland in the Southern Plains. 


\section{Materials and Methods}

This study was on the Southern Plains Experimental Range near Fort Supply in northwestern Oklahoma. The soil is predominately a deep loamy sand (Pratt series-sandy, mixed, thermic Psammentic Haplustalfs). Prior to cultivation, the land supported a sand sagebrush (Artemisia filifolia Torr.)-mixed grass prairie with sand bluestem (Andropogon hallii Hack.), sand dropseed (Sporobolus cryptandrus (Torr.) Gray), blue grama (Bouteloua gracilis (H.B.K.)Lag.), switchgrass (Panicum virgatum L.) and little bluestem (Schizachyrium scoparium (Michx.)Nash) as dominant grasses (Berg 1994).

The area was farmed for about 40 years before 'WW-Spar' Old World bluestem was established in the early $1980 \mathrm{~s}$. The Old World bluestem was fertilized with $68 \mathrm{~kg} \mathrm{~N} \mathrm{ha}^{-1} \mathrm{yr}^{-1}$ and grazed for the 2 years $(1986,1987)$ preceding initiation of this study. Analysis (Hanlon and Johnson 1983) of 5 soil samples of 30 cores each of the surface $15 \mathrm{~cm}$ had the following averages; nitrate was low (3 $\mathrm{mg} \mathrm{NO}_{3}-\mathrm{N} \mathrm{kg}^{-1}$, calcium sulfate extraction), $\mathrm{P}$ was adequate (32 $\mathrm{mg} \mathrm{P} \mathrm{kg}^{-1}$, Bray 1 extraction), $\mathrm{K}$ was adequate (280 $\mathrm{mg} \mathrm{K} \mathrm{kg}^{-1}$, ammonium acetate extraction), and $\mathrm{pH}$ was 5.5 (1:1 mass soil/mass distilled water).

A randomized complete block design was used with 4 blocks. This involved 16 paddocks and $4 \mathrm{~N}$ rates; $0,34,68$, and $102 \mathrm{~kg} \mathrm{~N}$ $\mathrm{ha}^{-1} \mathrm{yr}^{-1}$. The basic stocking was 3 test steers per paddock. "Put and take" steers were used in an attempt to maintain similar amounts of available forage per steer in each paddock over the summer grazing periods. Steer gain per paddock was the experimental unit used in the statistical analysis.

Paddocks were 1.2 ha for the control (no N) treatment and 0.8 ha for each $\mathrm{N}$ ferilized treatment. The $\mathrm{N}$ source was ammonium nitrate broadcast in April of each year. Incremental $N$ rates were obtained by adjusting a drop spreader for the $34 \mathrm{~kg} \mathrm{~N} \mathrm{ha}^{-1}$ rate and then double or triple spreading for the higher rates. Aftermath in all paddocks was burned at the start of the study in late March 1988, and again in March 1992. Aftermath was winter grazed after the 1988, 1989, and 1990 growing seasons, and standing residue mowed in March.
A low temperature of $-20^{\circ} \mathrm{C}$ on 22 December 1989 , following a dry fall (4 mm precipitation October through December 1989) resulted in extensive winterkill of Old World bluestem. To allow recovery, the bluestem was not grazed during the following (1990) growing season. However, $N$ was applied before the extent of the cold damage was realized, thus, the study was $\mathrm{N}$ fertilized over 5 years $(1988-1992)$ but only grazed during the growing seasons of 1988, 1989, 1991, and 1992.

Precipitation measured at the Southern Plains Experimental Range headquarters, about $1.5 \mathrm{~km}$ from the research site, was 500 $\mathrm{mm}$ in $1988 ; 680 \mathrm{~mm}$ in $1989,440 \mathrm{~mm}$ in $1990,410 \mathrm{~mm}$ in 1991 , and $480 \mathrm{~mm}$ in 1992. The 50 -year mean is $575 \mathrm{~mm} \mathrm{yr}^{-1}$.

Yearling steers were placed in the paddocks in early June when grass was 15 to $20 \mathrm{~cm}$ tall. Steers were grazed until late July or mid-August with the objective of maximizing Old World bluestem use while quality and growth rates were higher, and then allowing a regrowth period before fall dormancy (Table 1). The steers, Hereford or crosses of Hereford or Angus with Simmental, Limousin, or Brahman, were implanted with a growth promotant in May. Initial steer weights averaged $220 \mathrm{~kg}$ in 1988, $250 \mathrm{~kg}$ in 1989, $320 \mathrm{~kg}$ in 1991, and $235 \mathrm{~kg}$ in 1992. Steers were weighed at 3-week intervals, with the exception of a 2-week interval at the end of the 1988 summer grazing and a 4-week interval at the end of the 1989 summer grazing. Before weighing, steers were held for 18 hours without feed or water. Steer numbers in each paddock were adjusted after each weighing interval. Steer gain ha-1 was calculated as the average test steer daily gain between weighing intervals times steer days in paddock divided by ha in paddock; this data was then summed for all summer grazing periods within each year.

The quantity of forage in each paddock was determined when steers were placed in the paddocks and subsequently whenever the steers were weighed. The exception was that forage was not sampled on 14 August 1989 because the grass was severely hail damaged. A dormant season sampling was made each fall. At each sampling, forage was cut at a height of $7 \mathrm{~cm}$ from five 1.25 $\times 4 \mathrm{~m}$ areas within each paddock. Subsamples were dried at $60^{\circ} \mathrm{C}$ and oven dry yields calculated. Available forage was calculated

Table 1. Stocking density and available forage (kgtSE) per steer per grazing period over 4 years on $\mathrm{N}$-fertilization treatments on Old World bluestem.

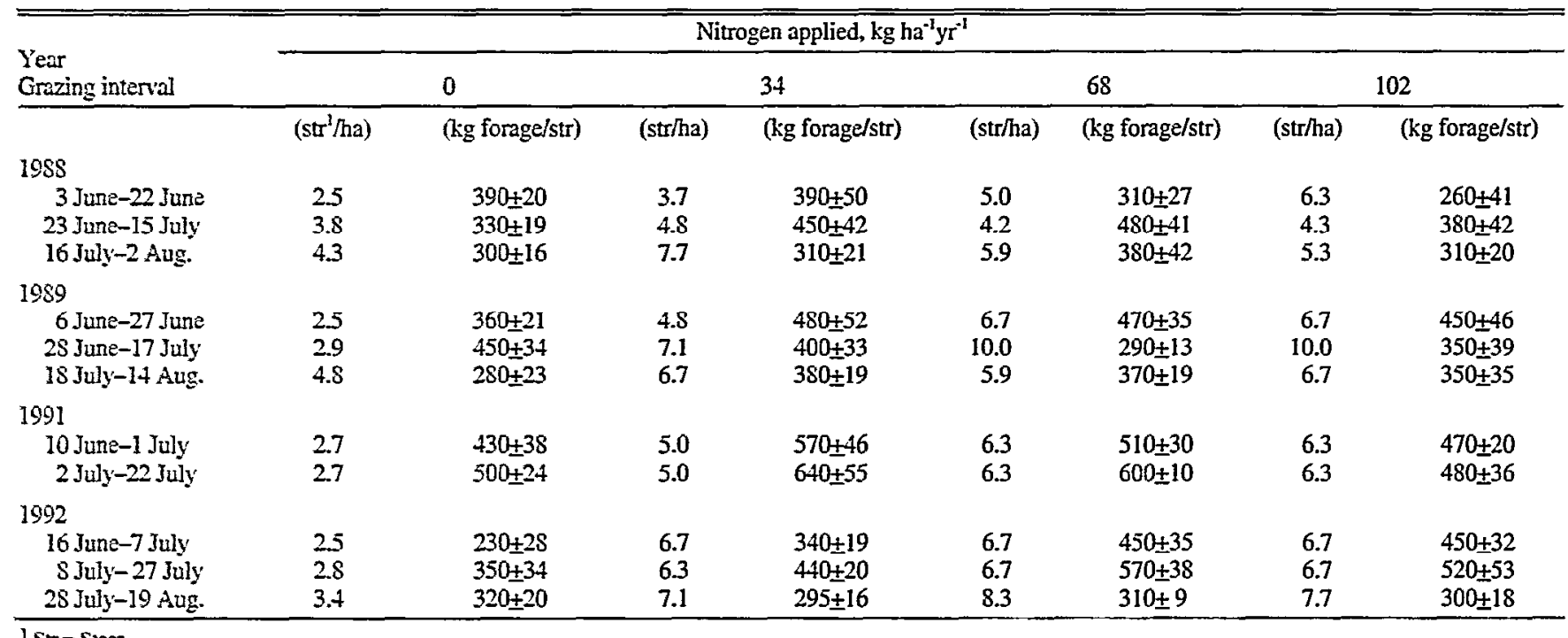


as the average of forage mass in each paddock at the start and end of each steer weighing period divided by the number of steers in the paddock over that period. Forage quality was determined by separating leaves from stems (White 1990) and then analyzing for $N$ (kjeldahl procedure, Bremner and Breitenbeck 1983) and in vitro dry matter digestibility (Tilley and Terry 1963). Nitrogen concentration was multiplied by 6.25 to estimate crude protein.

Aftermath was grazed by incoming stockers in the late fall and winter following the 1988, 1989, and 1990 growing seasons (Table 2). Aftermath was supplemented with $0.7 \mathrm{~kg} 41 \%$ protein cottonseed cake steer ${ }^{-1}$ day $^{-1}$. Grazing on aftermath was with herds of 25 to 30 steers placed in individual paddocks. Grazing management on aftermath was to graze an estimated $2 / 3$ to $3 / 4$ of the standing crop. Steer weight gains on aftermath were estimated from steer days in each paddock times an estimated average daily gain of $0.15 \mathrm{~kg}$ day $y^{-1}$. The estimated daily gain of $0.15 \mathrm{~kg}_{\text {day }}{ }^{-1}$ is from past grazing studies on Old World bluestem aftermath at the Experimental Range (Sims et al. 1983).

Table 2. Estimated steer gain on protein-supplemented dormant Old World bluestem.

\begin{tabular}{|c|c|c|c|c|}
\hline \multirow[t]{2}{*}{ Grazing Period } & \multicolumn{2}{|c|}{ N Rate } & \multicolumn{2}{|c|}{$\mathrm{kg} \mathrm{ha}^{-1} \mathrm{yr}^{-1}$} \\
\hline & 0 & 34 & 68 & 102 \\
\hline & \multicolumn{4}{|c|}{$\ldots \ldots \ldots$ kg steer gain ha-1 $\ldots \ldots$} \\
\hline 3 Jan. - 14 Fab. 1989 & 45 & 60 & 65 & 70 \\
\hline 6 Oct. 1989 - 3 Jan. 1990 & 45 & 70 & 95 & 100 \\
\hline 26 Dec. 1990 - 26 Feb. 1991 & 35 & 70 & 60 & 65 \\
\hline
\end{tabular}

Peak standing forage production was measured on 15 July 1988, 28 June 1989, and 1 July 1991 in $5 \times 150 \mathrm{~m}$ exclosures constructed between treatment paddocks. Exclosed areas were given $N$ treatments and five $1.25 \times 4 \mathrm{~m}$ areas harvested within each exclosure. In 1992, five $2.5 \times 5 \mathrm{~m}$ exclosures were randomly placed within each paddock and $1.25 \times 4 \mathrm{~m}$ areas harvested on 15 July within each exclosure for peak standing forage production.

Nitrogen fertilizer use efficiency in this report is the average steer gain increase per unit of $\mathrm{N}$ applied for a specified portion of a yield curve; this definition is synonymous to the term "yield efficiency" used in crop production (Bock 1984).

Analysis of variance was conducted for summer steer gain ha ${ }^{-1}$ as affected by $N$ rates over years and for each year, then treatment effects were partitioned into linear, quadratic, cubic, and residual components by year. The same analysis was used on peak standing forage production. Analysis of variance was conducted for average daily steer gain and forage quality. Duncan's new multiple range test $(P=0.05)$ was used to separate treatment effects on daily sterr gain.

\section{Results and Discussion}

Steer gain ha ${ }^{-1}$ during the 4 summer grazing seasons increased with $\mathrm{N}$ rates up to 34 or $68 \mathrm{~kg} \mathrm{~N} \mathrm{ha}{ }^{-1}$. The gain response to $\mathrm{N}$ rates was quadratic and is presented for each year (Fig. 1) because the year $\times \mathrm{N}$ rate interaction was significant $(P<0.01)$ in the combined analysis.

Steer gain over the 4 summer grazing seasons averaged $3.3 \mathrm{~kg}$

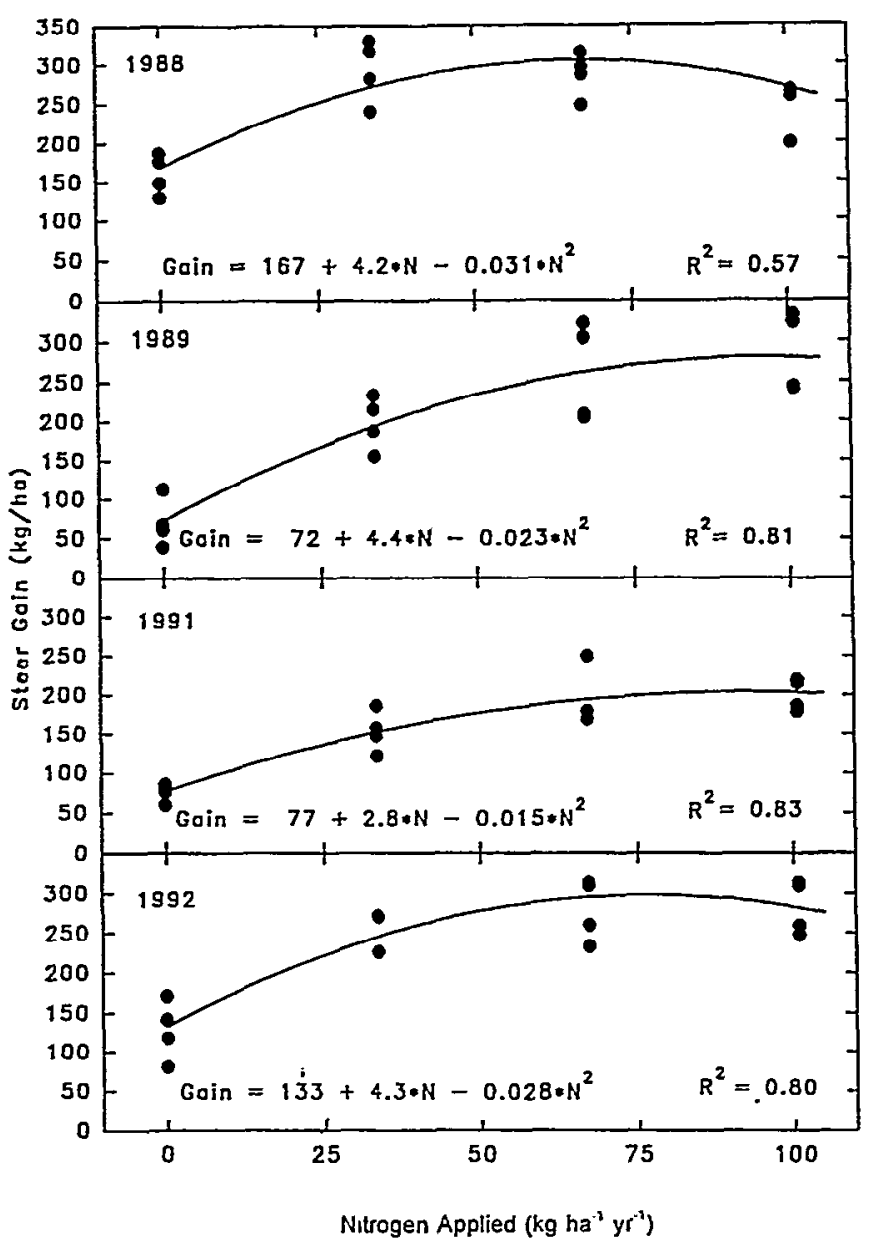

Fig. 1. Steer gain over 4 summer grazing seasons as affected by $\mathbf{N}$ rates applied to Old World bluestem established on marginal farmland in western Oklahoma.

per $\mathrm{kg} \mathrm{N}$ applied at the lowest $\mathrm{N}$ rate of $34 \mathrm{~kg} \mathrm{~N}^{-1}$. This $\mathrm{N}$ fertilizer use efficiency is greater than an average stocker gain of about $2 \mathrm{~kg}$ per $\mathrm{kg} \mathrm{N}$ applied reported in the southeastern USA (Wilkinson and Langdale 1974) and the Northern Great Plains (Rogler and Lorenz 1969, 1974). A range in N fertilizer use efficiency of 1.3 to $4.7 \mathrm{~kg}$ steer gain per $\mathrm{kg} \mathrm{N}$ applied was found for irrigated tropical pastures in Western Australia (Jones 1990).

Economic retum is currently favorable for the initial $34 \mathrm{~kg} \mathrm{~N}$ $\mathrm{ha}^{-1}$ increment used in our study with cost of applied $\mathrm{N}$ about $\$ 0.55 \mathrm{~kg}^{-1} \mathrm{~N}$ and custom grazing rates about $0.60 \mathrm{~kg}^{-1}$ of stocker gain. Returns would be marginal for the second $34 \mathrm{~kg} \mathrm{~N} \mathrm{ha}^{-1}$ increment (from 34 to $68 \mathrm{~kg} \mathrm{~N} \mathrm{ha}^{-1}$ ) applied in our study which averaged about one $\mathrm{kg}$ steer gain per $\mathrm{kg} \mathrm{N}$. Gain was negligible from the third $34 \mathrm{~kg} \mathrm{~N} \mathrm{ha}^{-1}$ increment (from 68 to $102 \mathrm{~kg} \mathrm{~N} \mathrm{ha}^{-1}$ ).

Steer gain in the unfertilized paddocks was surprisingly high, averaging $112 \mathrm{~kg} \mathrm{ha}^{-1} \mathrm{yr}^{-1}$ over 4 years. Part of this productivity is probably residual effect from $\mathrm{N}$ fertilization and cycling of $\mathrm{N}$ in the pastures in the 2 years prior to this study and also $\mathrm{N}$ fertilization of grazed annual forages since the early 1960s. Thus, this study site appears to be on land with a relatively high $\mathrm{N}$ availability level due to recent management. Some marginal farmland in 
1988

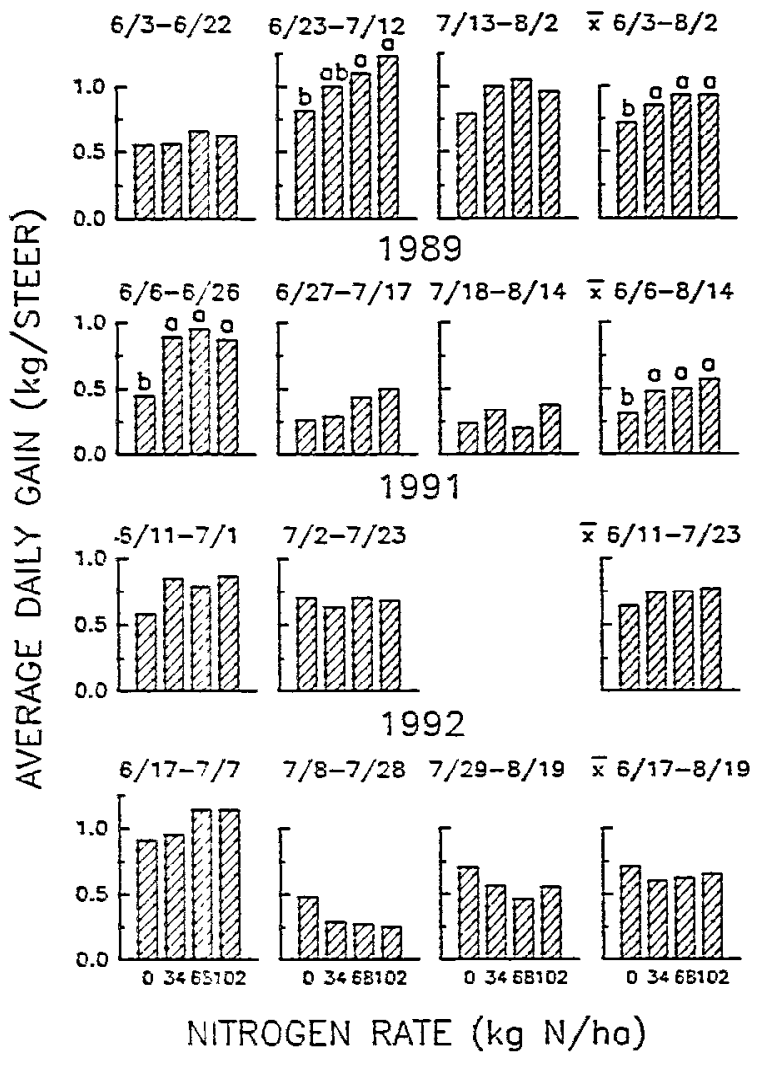

Fig. 2. Average daily steer gain during grazing intervals over 4 summer grazing seasons as affected by $\mathrm{N}$ application rates to Old World bluestem. Gain within a time interval designated with a common letter or no letter are not significantly $(P>0.05)$ different.

the Southern Plains is more N deficient (Berg 1990) and may produce an economical return to higher $N$ rates.

Daily gain averaged $0.70 \mathrm{~kg} \mathrm{steer}^{-1}$ and ranged from 0.3 to 0.9 $\mathrm{kg} \mathrm{steer^{-1 }}$ over the 4 summer grazing seasons (Fig. 2). Average daily gain was greater from $\mathrm{N}$-fertilized than from unfertilized treatments in 1988 and 1989, but no difference was found in 1991 or 1992. Nitrogen fertilization increased crude protein concentration but had little effect on forage digestibility (Table 3 ).

The daily gain averaging $0.70 \mathrm{~kg}_{\text {day }}{ }^{-1}$ for the $\mathrm{N}$-fertilized Old World bluestem over 4 years is less than daily gain averaging $0.97 \mathrm{~kg} \mathrm{day}^{-1}$ for similar steers grazing nearby native range (unpublished data P. L. Sims) over the same time period. Average daily gain was disappointingly low during the second and third grazing intervals in 1989 and 1992 (Fig. 2). In these years above normal summer rainfall resulted in accelerated forage growth in the N-fertilized treatments (Fig. 3), consequently, stocking was increased (Table 1).

A growth characteristic of Old World bluestem is rapid growth in late May through June with the fully headed stage reached in early July. We estimated that peak standing crop (Fig. 3) occurs at the fully headed stage when leaves averaged $62 \%$ of the forage harrested in the exclosures. The forage yield response to $\mathrm{N}$ rates was quadratic and is presented for each year because the year $\times N$ rate interaction was significant $(P<0.01)$ in the combined analysis. Peak standing forage production ranged from $1,200 \mathrm{~kg} \mathrm{ha}^{-1}$ in
Table 3. Forage quality of Old World bluestem in grazed pastures as a function of $N$ rates and dates, 1988. Data from the other 3 years are similar and is not reported.

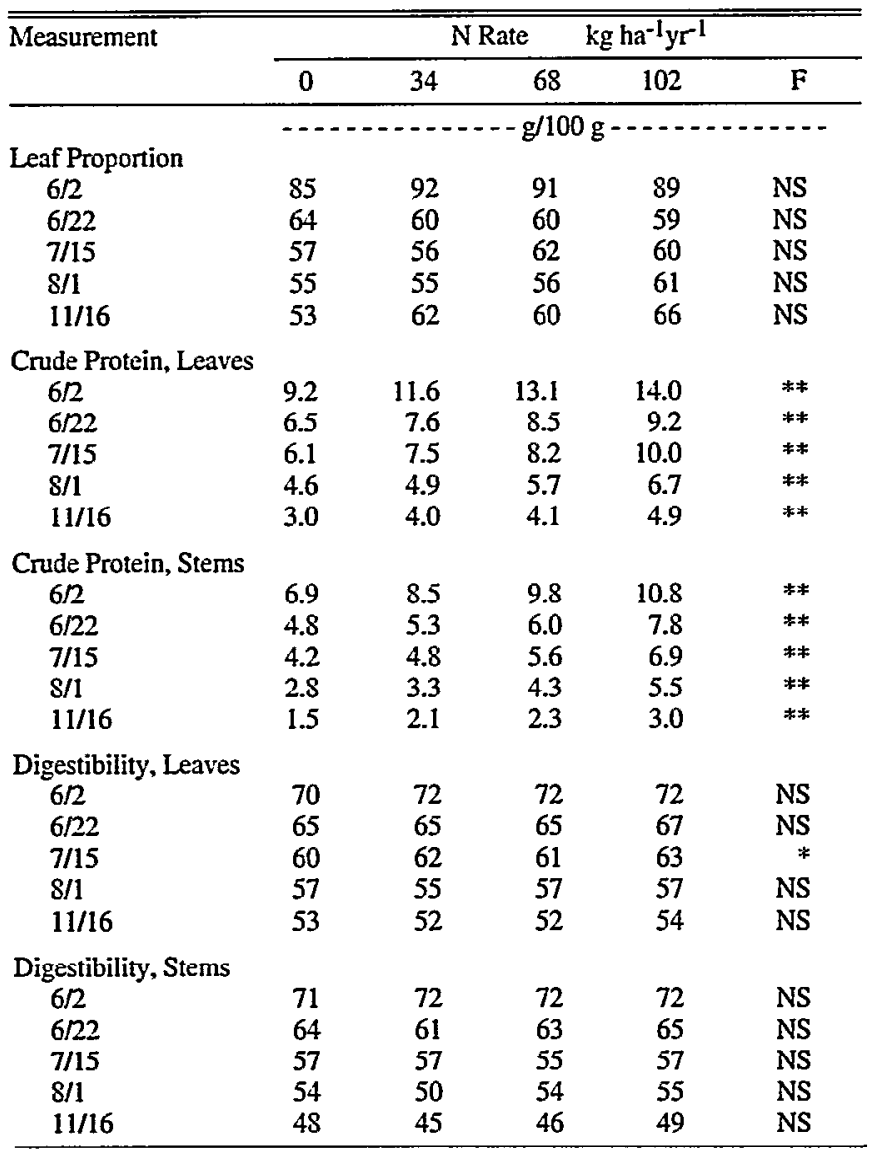

NS $=$ non-significant, ${ }^{*}=$ significant at the $P \leq 0.05,{ }^{* *}=$ significant at the $P \leq 0.01$.

1992 on paddocks receiving no $\mathrm{N}$ fertilizer, to near $6,900 \mathrm{~kg} \mathrm{ha}^{-1}$ in 1989 on the higher $\mathrm{N}$ rate treatments (Fig. 3). Available forage averaged $400 \mathrm{~kg}$ per steer over the 4 summer grazing seasons (Table 1).

Grazing of aftermath during the dormant season resulted in estimated steer gains on $\mathrm{N}$ fertilized treatments of 15 to $55 \mathrm{~kg} \mathrm{ha}^{-1}$ greater than the no $\mathrm{N}$ treatment (Table 2). The difference in dormant season gain between the $\mathrm{N}$-fertilized and no $\mathrm{N}$ treatments should be attributed to both $\mathrm{N}$ fertilizer and more protein supplement fed to supplement the greater amount of forage in the $\mathrm{N}$ treatments. Because of this, and because steer gain on aftermath was only estimated, no additional value for $\mathrm{N}$ fertilizer use efficiency on the dormant season grazing was calculated. However, dormant season grazing would add to the $\mathrm{N}$ fertilizer use efficiency previously calculated for summer grazing.

Stocking management appears critical to optimizing summer stocker gain on Old World bluestem. Grass growth stage when grazing starts appears to be particularly important. For example, steers were placed in the paddocks on 3 June 1988 when growth was mostly leaves ( $89 \%$, Table 3 ). The initial stocking density of 6.2 steers ha-1 on the $102 \mathrm{~kg} \mathrm{~N}^{-1} \mathrm{a}^{-1}$ treatment proved too high and was reduced (Table 1). Whereas, in 1989, 1991, and 1992 with a later turn-in, both in terms of calendar date (Table 1) and grass phenological development the stocking density of 6.2 steers ha ${ }^{-1}$ was sustainable. However, Old World bluestem forage quality 


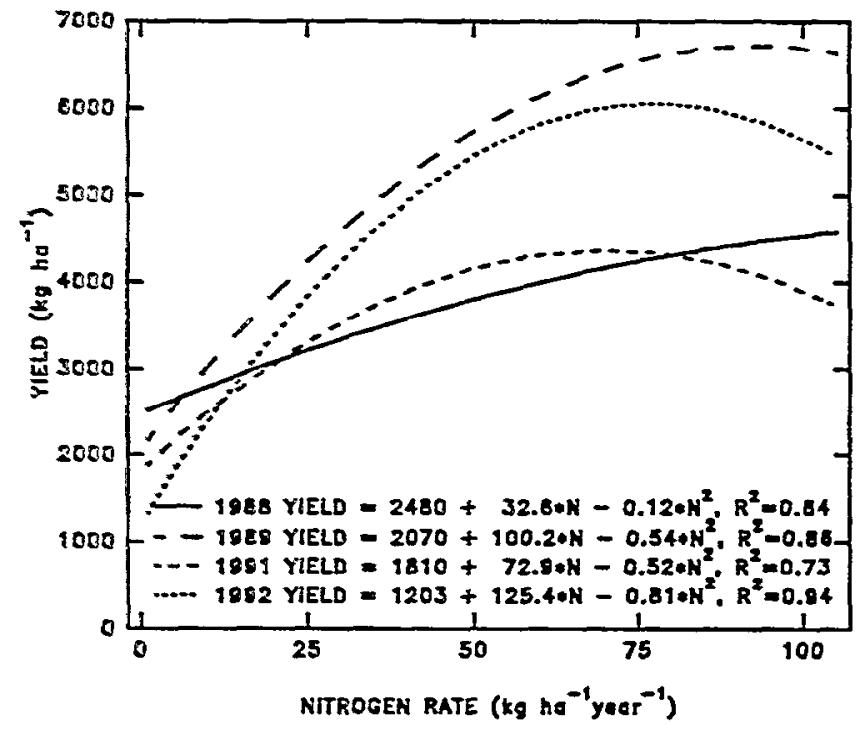

Fig. 3. Peak standing forage production by Old World bluestem as affected by $\mathrm{N}$ application rates.

decreased rapidly with time (Table 3) usually resulting in lower daily gain after the initial 3-week grazing period (Fig. 2). Put and take stocking as used in this study is seldom a viable alternative in commercial operations. With set stocking, the timing of turn in would be even more critical.

Previous studies show that Old World bluestem fertilized with $68 \mathrm{~kg} \mathrm{~N} \mathrm{ha}{ }^{-1} \mathrm{yr}^{-1}$ produced steer gain averaging $200 \mathrm{~kg} \mathrm{ha}^{-1} \mathrm{yr}^{-1}$ under December through September stocking at about 1.7 steers $\mathrm{ha}^{-1}$ (Sims et al. 1983). This study provides data on an alternative management with early summer grazing resulting in average steer gain of $220 \mathrm{~kg} \mathrm{ha}^{-1} \mathrm{yr}^{-1}$ with stocking averaging about 5 steers ha-1 and $N$ application of $34 \mathrm{~kg} \mathrm{ha}^{-1} \mathrm{yr}^{-1}$. Part of this potential might be used to reduce growing season grazing pressure on native rangeland. A $\mathrm{N}$ application rate of about $34 \mathrm{~kg} \mathrm{ha}^{-1} \mathrm{yr}^{-1}$ appears to be most efficient for pastures with a history of $N$ fertilization in this climatic zone. A higher $\mathrm{N}$ rate is suggested for stands that do not have a history of $\mathrm{N}$ fertilization or are hayed.

\section{Literature Cited}

Eerg, W. A. 1990. Old World bluestem responses to nitrogen fertilization. J. Range Manage. 43:265-270.

Berg, W. A. 1994. Sand sagebrush-mixed prairie. p. 99. In: T. N. Shiflet (ed.) Rangeland cover types of the United States. Soc. Range Manage. Danver, Colo.

Rock, F. R. 1984. Efficient use of nitrogen in cropping systems. p. 273-294. In: R. D. Hauck (ed.) Nitrogen in crop production. Amer. Soc. Agron. Madison. Wis.

Eremner, J. M. and G. A. Breitenbeck. 1983. A simple method for determinetion of ammonium in semimicro-kjeldahl analysis of soils and plant materials using a block digester. Commun. Soil Sci. Plant Anal. 14:905-913.

Dewald, C. L., W. A. Berg, P. L. Sims. 1985. New seed technology for old farmland. J. Soil Water Conserv. 40:277-279.

Eanlon, E. and G. Johnson. 1983. OSU agronomic services procedure for soil, forage and water testing. OSU Extension Facts 2901. Oklahoma State Univ. Coop. Ext. Ser. Stillwater, Okla.
Jones, R. J. 1990. Nitrogen rate and stocking rate effects on steer gains from grazed pangola grass in the Ord Valley, Western Australia. Australian J. Exp. Agr. 30:599-605.

Rogler, G. A. and R. J. Lorenz. 1969. Pasture productivity of crested wheatgrass as influenced by nitrogen fertilization and alfalfa. USDAARS Technical Bull. 1402.

Rogler, G. A. and R. J. Lorenz. 1974. Fertilization of mid-continent range plants. p. 231-254. In: D. A. Mays (ed.) Forage Fertilization. Amer. Soc. Agron. Madison, Wis.

Russelle, M. P. 1992. Nitrogen cycling in pasture and range. J. Prod. Agric. 5:13-23.

Shoop, M. C. and E. H. McIlvain. 1971. Efficiency of combining improvement practices that increase steer gains. J. Range Manage. 24:113-116.

Sims, P. L., C. L. Dewald, and S. Cowles. 1983. Advances with Old World bluestems. p. 4-11. In: H. T. Wiedemann and J. F. Cadenhead (compilers), Proc. Range and Pasture Seeding in the Southern Great Plains. Oct. 1983, Vemon, Texas. Texas A\&M Univ. Agr. Res. Ext. Center, Vernon, Tex.

Tilley, J. M. A. and R. A. Terry. 1963. A two stage technique for the in vitro digestion of forage crops. J. Brit. Grassl. Soc. 18:104-111.

Wilkinson, S. R. and G. W. Langdale. 1974. Fertility needs of warmseason grasses. p. 119-145. In D. A. Mays (ed.) Forage Fertilization. Amer. Soc. Agron. Madison, Wis.

White, L. M. 1990. Mefluidide effect on Caucasian bluestem leaves, stems, forage yield and quality. J. Range Manage. 43:190-194.

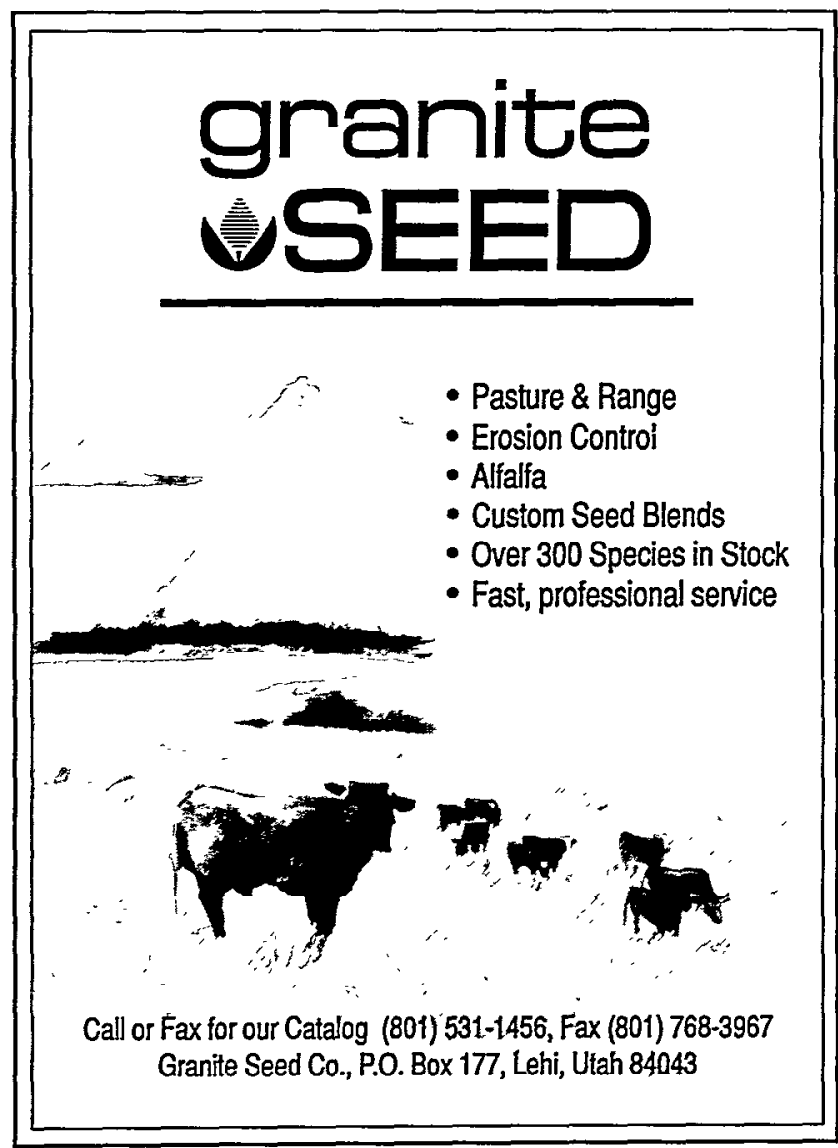

